\title{
Low band gap polymers for organic solar cells
}

\author{
Bundgaard, Eva; Krebs, Frederik C
}

Published in:

Organic Photovoltaics 7

Link to article, DOI:

$10.1117 / 12.679012$

Publication date:

2008

Document Version

Publisher's PDF, also known as Version of record

Link back to DTU Orbit

Citation (APA):

Bundgaard, E., \& Krebs, F. C. (2008). Low band gap polymers for organic solar cells. In Z. H. Kafafi, \& P. A. Lane (Eds.), Organic Photovoltaics 7 (Vol. 6334). [63340T] SPIE - International Society for Optical Engineering. Proceedings of SPIE - The International Society for Optical Engineering https://doi.org/10.1117/12.679012

\section{General rights}

Copyright and moral rights for the publications made accessible in the public portal are retained by the authors and/or other copyright owners and it is a condition of accessing publications that users recognise and abide by the legal requirements associated with these rights.

- Users may download and print one copy of any publication from the public portal for the purpose of private study or research.

- You may not further distribute the material or use it for any profit-making activity or commercial gain

- You may freely distribute the URL identifying the publication in the public portal

If you believe that this document breaches copyright please contact us providing details, and we will remove access to the work immediately and investigate your claim. 


\title{
Low band gap polymers for organic solar cells
}

\author{
Eva Bundgaard ${ }^{a, b}$ and Frederik C. Krebs ${ }^{a}$ \\ a Polymer Solar Cell Initiative, The Danish Polymer Centre, Ris $\phi$ National Laboratory, \\ PO Box 49, DK-4000 Roskilde, Denmark. \\ ${ }^{b}$ Institute for Biology and Chemistry, Roskilde Universitycenter, Universitetsvej 1 , \\ PO Box 260, DK-4000 Roskilde, Denmark.
}

\section{Abstract}

The synthesis of copolymers based on thiophene, benzothiadiazole and benzobis(thiadiazole) is presented. The band gaps were estimated from UV-vis and the electron structure of the polymers were determined by Ultraviolet photoelectron spectroscopy (UPS). Results for some photovoltaic devices are given.

\section{Introduction}

The use of low band gap polymers for organic photovoltaic are believed to increase the efficiency of the device by a better overlap with the solar spectrum. The synthesis of low band gap polymers are however a challenge and only a few examples have been reported. The most important ones are polythiophene, polyisothianaphthene and copolymers of benzothiadiazole, thiophene and pyrrole with band gaps of 2.0, 1.2 and $1.6 \mathrm{eV}$, respectively. Here we present the synthesis and characterization of copolymers based on thiophene, benzothiadiazole and benzobisthiadiazole.

Synthesis

Monomers:
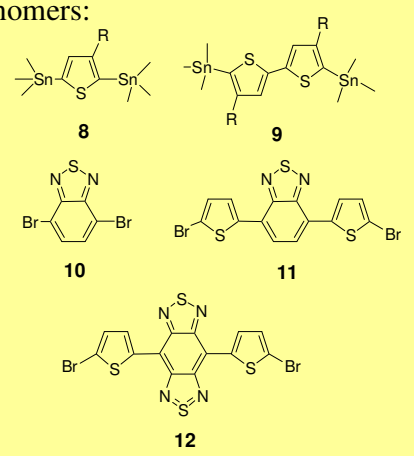

Stille cross coupling polymerization:

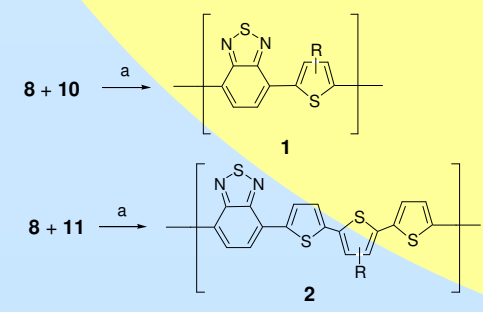

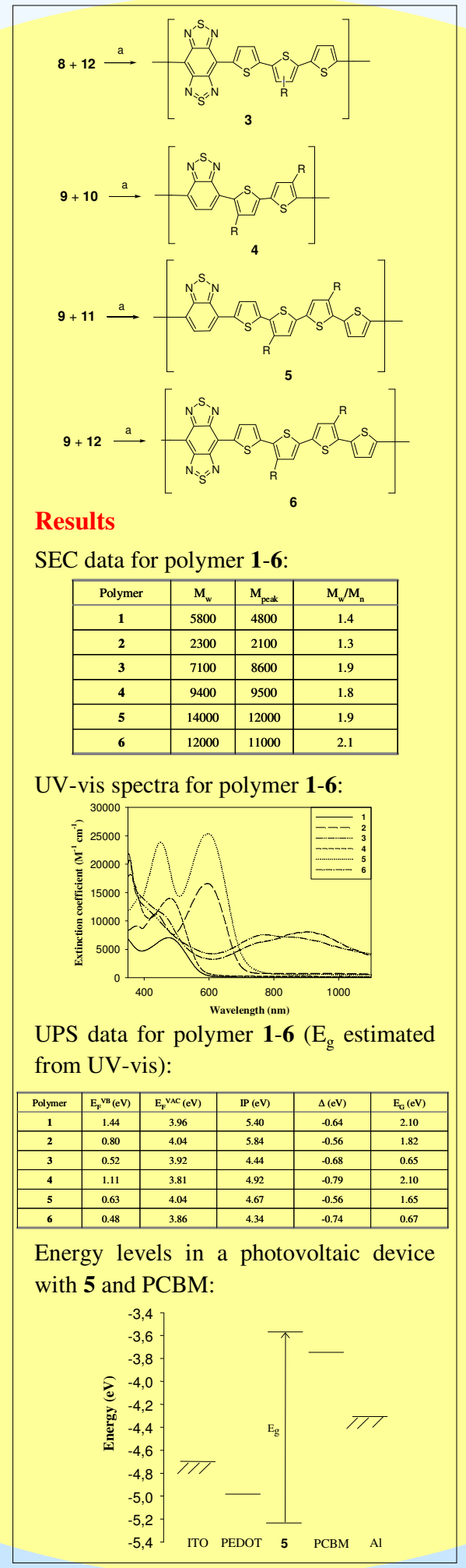

Photovoltaic devices were prepared with polymer $\mathbf{5}$ and with a blend of polymer $\mathbf{5}$ and PCBM. The photovoltaic performance for these devices is summarized in the table below.

\begin{tabular}{|l|c|c|c|c|}
\hline Device & $\mathrm{V}_{\mathrm{OC}}(\mathrm{V})$ & $\mathrm{I}_{\mathrm{SC}}\left(\mathrm{mA} \mathrm{cm}^{-2}\right)$ & $\mathrm{FF}(\%)$ & $\eta(\%)$ \\
\hline $\mathbf{5}, 3 \mathrm{~cm}^{-2}$ & 0.69 & -0.012 & 25 & 0.001 \\
\hline $\mathbf{5} / \mathrm{PCBM}(1: 2), 3 \mathrm{~cm}^{-2}$ & 0.58 & -2.70 & 38 & 0.6 \\
\hline $\mathbf{5} /$ PCBM $(1: 2), 10 \mathrm{~cm}^{-2}$ & 0.56 & -1.29 & 28 & 0.2 \\
\hline
\end{tabular}

IV-curve for the polymer $\mathbf{5}$ and PCBM:

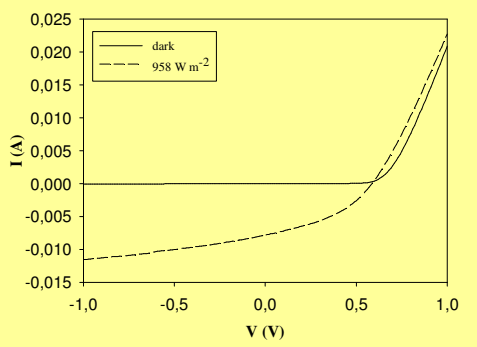

The photovoltaic studies showed:

- $\mathrm{I}_{\mathrm{SC}}$ increased when PCBM was added.

- Highest $\eta$ for 5/PCBM 1:2 ratio.

- $\mathrm{I}_{\mathrm{SC}}$ and $\eta$ decreases with increase in area (3 and $10 \mathrm{~cm}^{2}$ devices).

- Lifetime of less than 2 hours for non encapsulated devices.

- IPCE of $22 \%$ at $560 \mathrm{~nm}$ for ITO-PDOT5/PCBM (1:2)-Al.

Conclusion

Low band gap copolymers based on thiophene, benzothiadiazole and benzobis-thiadiazole were synthesized by Stille cross coupling polymerization and the band gaps were estimated to $2-1.7 \mathrm{eV}$ for polymers based on benzothiadiazole and $0.7 \mathrm{eV}$ for polymers based on benzobis(thiadiazole).

Polymer 5 was applied in large area photovoltaic devices $\left(3\right.$ and $\left.10 \mathrm{~cm}^{2}\right)$ with the configuration ITO-PEDOT-5/PCBM (1:2)-Al which gave a efficiency up to $0.6 \%$. Further work is in progress to apply all polymers in OPV and to improve the efficiency of the devices with polymer 5 . 